\title{
Influence of Age on the Selenium Status in Belgium and The Netherlands
}

\author{
M. VAN CAILLIE-BERTRAND,${ }^{1}$ H. J. DEGENHART, ${ }^{2}$ AND J. FERNANDES \\ Department of Pediatrics, Erasmus University Rotterdam, University Hospital Rotterdam/Sophia Children's \\ Hospital, Rotterdam, The Netherlands
}

\begin{abstract}
Plasma selenium concentration and glutathione peroxidase activity in red blood cells were determined in subjects from different age groups. The selenium level (mean \pm SD) found in infancy (0 to 6 months) was $2 \pm 0.6$ $\mu \mathrm{g} / \mathrm{dl}$, with the lowest value of $1 \mu \mathrm{g} / \mathrm{dl}$ observed in a 4month-old infant. These levels were significantly lower $(p$ $<0.001$ ) than the value of $9.5 \pm 1.1 \mu \mathrm{g} / \mathrm{dl}$ found in the adult group and $7.7 \pm 1.3 \mu \mathrm{g} / \mathrm{dl}$ found in the group of older children ( 2 to $15 \mathrm{yr}$ ). Younger children (6 to 24 months of age) had intermediate levels of $5 \pm 1.2 \mu \mathrm{g} / \mathrm{dl}$. When the data were plotted on a logarithmic scale as a function of age, the figure shows clearly that the plasma selenium levels increase steadily with age throughout life after an initial drop at 60 to 90 days. There was a satisfactory correlation between the plasma selenium concentration and the enzyme glutathione peroxidase activity in the red blood cells (Spearman's $\rho=0.45, p<0.005$ ). Although very low selenium values were observed, the enzyme glutathione peroxidase activity remained above $10 \mathrm{U} / \mathrm{g}$ hemoglobin (with only one exception) in all patients. (Pediatr Res 20: 574-576, 1986)
\end{abstract}

\section{Abbreviations}

GSH-Per, enzyme glutathione peroxidase

Hb, hemoglobin

Selenium is an essential nutrient for animals: it was recognized as such in 1957 when Schwarz (1) showed in rats that selenium deficiency leads to necrotic degeneration of liver, pancreas, kidney, and heart. It was not until 1979, however, that the existence of a human requirement for selenium was described, when Van Rij et al. (2) observed a patient on total parenteral nutrition who developed tenderness in the thighs with inability to walk. This syndrome responded within $1 \mathrm{wk}$ to selenium supplementation given as sole therapy (2). Almost simultaneously an endemic cardiomyopathy, occurring mainly in infants and children and known in China as Keshan disease, was reported to be prevented with supplementation of selenium (3), confirming the growing evidence that selenium might be essential for the function of the heart and other muscles in man. Although selenium is found in a muscle protein (1), its only well characterized and essential

Received December 13, 1985; accepted February 11, 1986.

All correspondence and requests for reprints should be sent to H. J. Degenhart, Department of Pediatrics, Erasmus University Rotterdam, University Hospital Rotterdam/Sophia Children's Hospital, Gordelweg 160, 3038 GE Rotterdam, The Netherlands.

This study was sponsored by the Sophia Foundation for Medical Research, Sophia Children's Hospital, Rotterdam, The Netherlands.

'Present address General Children's Hospital, Antwerp, Belgium.

${ }^{2}$ Present address University Hospital, Department of Pediatrics, Groningen, The Netherlands. biochemical function in mammals is in the enzyme glutathione peroxidase (GSH-Per, EC 1.11.1.9), which is known to be subjected to a cyclic redox change during its catalytic action (4). This enzyme has a major function in the removal of $\mathrm{H}_{2} \mathrm{O}_{2}$ and organic peroxides generated during oxidative metabolism in cells and tissues, providing an efficient means of defense against the build-up of such peroxides which otherwise are able to damage cell membranes and macromolecules including DNA (5). It also interacts at two sites of the arachidonic acid cascade, preventing the accumulation of prostaglandin $\mathrm{G}$ (essential for the inflammatory responses of tissues) and regulating prostacyclin biosynthesis which inhibits the aggregation and adhesion of platelets to the endothelial lining of blood vessels (6).

Selenium levels in adult man have been shown to correlate with the selenium content of soils and foods (7). The determination of the selenium requirement is therefore of particular importance in those countries where the selenium intake is borderline, as is the case in Belgium and The Netherlands (8). Few data are presented in the literature on the selenium status of growing infants, children, adults, and elderly in Western Europe. To obtain this information, plasma selenium levels and activity of GSH-Per red blood cells were determined as possible functional parameters of adequate selenium status in subjects from different age groups.

\section{MATERIALS AND METHODS}

Blood samples were obtained from 25 infants (0-24 months of age), all receiving the same humanized cow's milk infant formula (Almiron, Nutricia) and from 16 children (2-15 yr of age) who had to undergo either minor operations or diagnostic procedures or were seen at the outpatient department at a last follow-up visit after an acute illness. All were growing well and had a height and weight $>$ P3 for age. Ten adults were members of the laboratory staff, five were healthy relatives and five were seen at the Department of Medicine for minor complaints.

All samples were collected and stored in metal free tubes. After centrifugation at $1250 \times g$, plasma and red blood cells were separated and kept frozen at $-70^{\circ} \mathrm{C}$ until analysis. The glutathione peroxidase activity of the red cells was measured at $30^{\circ} \mathrm{C}$ in a Zeiss PMQ III spectrophotometer, using the coupled test procedure with the substrate t-butylhydroperoxide as described by Paglia and Valentine (9); results were expressed as units per gram $\mathrm{Hb}$. One unit was defined as the amount of enzyme required to catalyse the oxidation of $1 \mathrm{nmol}$ NADPH under the conditions of the assay. Storage of frozen samples at $-70^{\circ} \mathrm{C}$ was shown to have no effect on enzyme activity. Reduced glutathione, glutathione reductase, and NADPH were obtained from Boehringer Mannheim. The plasma selenium concentrations were determined by the fluorometric method of Watkinson (10). 2,3Diamino-naphtalene (Fluka) was used as complexing reagent and cyclohexane (Baker) as the extracting solvent for the complex. The fluorescence was measured in a Baird-Atomic fluorom- 
eter model SF-1. Excitation wavelength $=366 \mathrm{~nm}$; fluorescence wavelength $=516 \mathrm{~nm}$. The selenium content was expressed as $\mu \mathrm{g} / \mathrm{dl}$.

\section{RESULTS}

Figure 1 reports the plasma levels of selenium from all 61 subjects as a function of age on a logarithmic scale. The solid line is a computer-drawn cubic spline fitted on the data points. As shown in Figure 1, the mean ( \pm SD) plasma selenium concentration found in the very young infants $(0$ to 6 months of age) approximates $2 \pm 0.6 \mu \mathrm{g} / \mathrm{dl}$ (range $1-3.2 \mu \mathrm{g} / \mathrm{dl}$ ). This value is significantly lower $(p<0.001)$ than $9.5 \pm 1.1 \mu \mathrm{g} / \mathrm{dl}$ concentration found in the adults (range 7.2-11.6 $\mu \mathrm{g} / \mathrm{dl}$ ) or the value of $7.7 \pm 1.3 \mu \mathrm{g} / \mathrm{dl}$ found in the older children (range $5.3 \mu \mathrm{g} / \mathrm{dl}-10.4$ $\mu \mathrm{g} / \mathrm{dl})$. Children 6 to 24 months of age had intermediate levels with a mean $( \pm \mathrm{SD})$ of $5 \pm 1.2 \mu \mathrm{g} / \mathrm{dl}$ (range $2.8-7.3 \mu \mathrm{g} / \mathrm{dl}$ ).

Figure 2 shows the correlation between the plasma selenium concentration and the red blood cell glutathione peroxidase activities in 44 subjects (Spearman's $\rho=0.45 ; p<0.005$ ). Although low selenium values were observed in the very young infants, the glutathione peroxidase activity remained above 10 $\mathrm{U} / \mathrm{g} \mathrm{Hb}$. Most remarkably the mean activity found in the group of young infants $(18.2 \pm 6.8 \mathrm{U} / \mathrm{g} \mathrm{Hb})$ did not differ significantly from the value found in the 6- to 24-month-old group (18.1 \pm $6.8 \mathrm{U} / \mathrm{g} \mathrm{Hb}$ ) nor from the value found in the group of older children $(22.5 \pm 7 \mathrm{U} / \mathrm{g} \mathrm{Hb})$. Mean adult glutathione peroxidase activity was $27 \pm 8 \mathrm{U} / \mathrm{g} \mathrm{Hb}$ (range 10.5-40 U/g Hb). This value does not differ significantly from the level found in infants.

\section{DISCUSSION}

Only a few studies on the selenium status of growing children have been published (11-13). The plasma selenium concentrations we report in infants fed humanized cow's milk formula and in children and adolescents with an adequate nutritional status as assessed by growth parameters agree well with the findings of Lombeck et al. (11) in Germany. This confirms the fact that circulating selenium in man as well as in animals (14) is age dependent. It also extends the existing information to the Benelux countries (Belgium, The Netherlands, Luxemburg) of Western Europe.

We observed the lowest values of selenium in infants 60 to 90 days old, and these levels were comparable to those reported in adults with clinical selenium deficiency (2). The plasma selenium

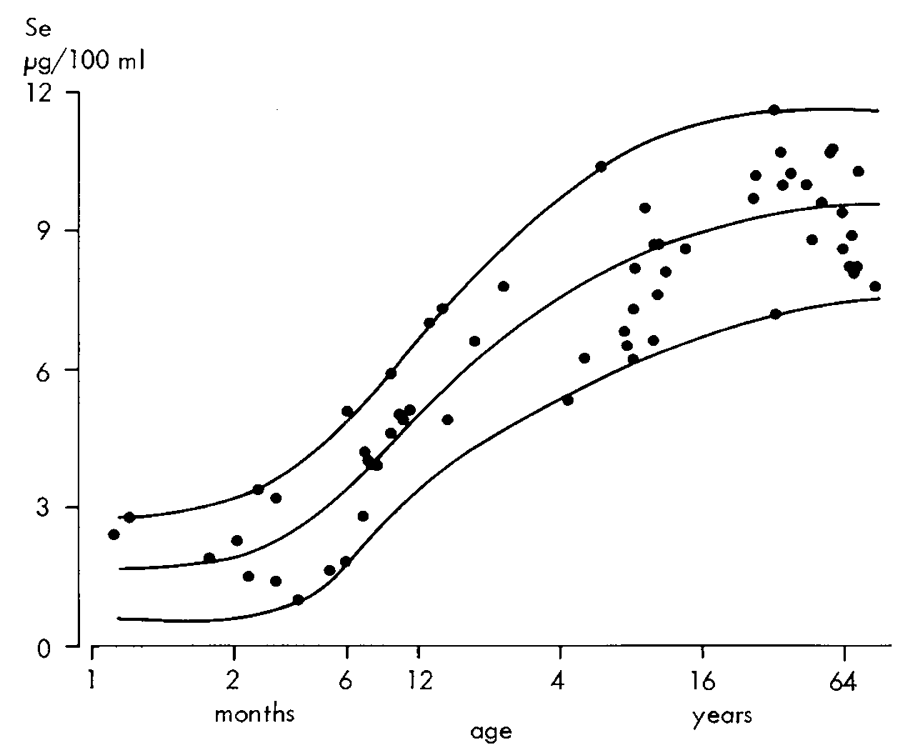

Fig. 1. Selenium concentrations in plasma of 61 individuals of different ages. Mean value with $95 \%$ confidence limits are shown.

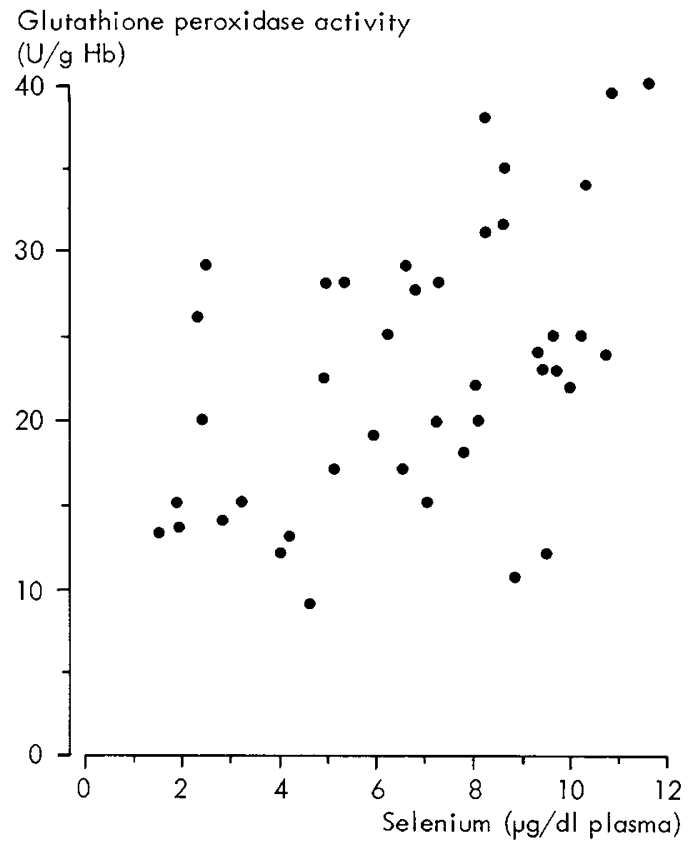

Fig. 2. Plasma selenium concentrations and glutathione peroxidase activities in red blood cells of 44 individuals of different ages.

levels of healthy adults from The Netherlands are comparable to the values found in Germany (11) and Finland (13). They are two to three times lower than the levels observed in the residents of the United States, Canada, or Japan where values up to 17$22 \mu \mathrm{g} / \mathrm{dl}$ are found (1). According to Valentine et al. (15) selenium deficiency is improbable with plasma selenium concentrations above $10 \mu \mathrm{g} / \mathrm{dl}$. By this standard the levels reported in adults are borderline and those observed in infants and children are dramatically low.

Selenium levels have been reported to correlate well with the selenium content of the diet (7). Calculated daily intakes are low in The Netherlands but also in all the north of Western Europe including Sweden, Finland, and West Germany (8). The extremely low levels in infants in the present study ( $\mathrm{ca} 10 \%$ of adult values) are most probably due to the low selenium content of cow's milk as compared to human milk (16), but could also be due to the insufficient availability and/or storage of selenium during pregnancy, the cord levels being a function of mother's selenium status (17). This latter, as shown in Figure 1, is on the borderline and sometimes even inadequate in the countries where the daily intake of selenium is low.

In agreement with earlier reports $(4,5,11,12)$, we found a positive correlation between the plasma selenium level and the GSH-Per activity in red blood cells. The fact that this relationship exists suggests at least a relative selenium deficiency in the infants with low plasma selenium values. Indeed the enzyme activity, in adults, depends strongly on the selenium supply until a plateau of activity is reached (4). There is now accumulating evidence that the activity of GSH-Per is submaximal at selenium concentrations of less than $10 \mu \mathrm{g} / \mathrm{dl}$. The GSH-Per activities in the present group of young infants are lower but not significantly different from those seen in older children and adults, despite their very low plasma selenium values. Whether this reflects Se status at the moment of red blood cell formation or the activity of a nonselenium dependent GSH-Per in this age group is not clear.

The existence in Western Europe of a causal relationship between low selenium levels and a clinical disorder has not yet been convincingly demonstrated. Nevertheless a subacute deficiency existing for some time might induce a metabolic or histopathological change which in turn could trigger a disease at some future time when the deficiency itself may not be detectable 
(4). In this regard, the study of Salonen et al. (18) describing a correlation between a subacute selenium deficiency and myocardial infarction and cardiovascular diseases is particularly important. Further epidemiological studies are needed. A more practical and direct way to detect and quantify lipid peroxidation and the influence of the selenium status on this process is probably the measurement of alkanes such as ethane and pentane (19).

Acknowledgements. The authors thank Mrs. H. de LeeuwBoon for the selenium determinations, H. Verweyen and Mrs. $\mathrm{N}$. de Kort for the glutathione peroxidase assay, and Mrs. K. Wielsma for secretarial help.

\section{REFERENCES}

1. Schwarz K 1976 Essentiality and metabolic functions of selenium. Med Clin North Am 60:745-758

2. Van Rij AM, Thomson CD, McKenzie JM, Robinson MF 1979 Selenium deficiency in total parenteral nutrition. Am J Clin Nutr 32:2076-2083

3. 1979 Selenium in the heart of China. Lancet 2:889-890

4. Flohé LW, Günzler WA, Loschen G 1979 The glutathione peroxidase reaction: a key to understand the selenium requirement of mammals. In: Kharasch $\mathrm{N}$ (ed) Trace Metals in Health and Disease. Raven Press, New York, pp 263 285

5. Stadtman TC 1980 Selenium-dependent enzymes. Ann Rev Biochem 49:93110

6. 1981 Selenium containing glutathione peroxidase: its synthesis and function in arachidonate metabolism. Nutr Rev 39:21-23

7. Thomson CD, Robinson MF 1980 Selenium in human health and disease with emphasis on those aspects peculiar to New Zealand. Am J Clin Nutr 33:303323

8. Verlinden M 1981 De bepaling van selenium door atomaire absorptie spectrometrie: methodologie en biomedische toepassingen. Proefschrift. Universitaire Instelling, Antwerpen

9. Paglia DE, Valentine WN 1967 Studies on the quantitative and qualitative characterisation of erythrocyte glutathione peroxidase. $\mathrm{J}$ Lab Clin Med 70:158-169

10. Watkinson $\mathrm{JH} 1966$ Fluorometric determination of selenium in biological material with 2.3-diaminonaphtalene. Anal Chem 38:92-97

11. Lombeck I, Kasperek K, Harbisch HD, Feinendegen LE, Bremer HJ 1977 The selenium state of healthy children. Eur J Pediatr 125:81-88

12. McKenzie RL, Rea HM, Thomson CD, Robinson MF 1978 Selenium concentration and glutathione peroxidase activity in blood of New Zealand infants and children. Am J Clin Nutr 31:1413-1418

13. Westermack T, Raunu P, Kirjarinta M, Lappalainen L 1977 Selenium content of whole blood and serum in adults and children of different ages from different parts of Finland. Acta Pharmacol Toxicol 40:465-475

14. Pinto RE, Bartley W 1969 The effect of age and sex on glutathione reductase and glutathione peroxidase activities and on aerobic glutathione oxidation in rat liver homogenates. Biochem J 112:109-115

15. Valentine JL, Kang HK, Schluchter M 1980 Selenium concentrations and glutathione peroxidase activities in a population exposed to selenium via drinking water. J Toxicol Environ Health 6:731-736

16. Lombeck I, Kasperek K, Bonnermann B, Feinendegen LE, Bremer HJ 1978 Selenium content of human milk, cow's milk and cow's milk infant formulas. Eur J Pediatr 129:139-145

17. Rudolph N, Wong SL 1978 Selenium and glutathione peroxidase activity in maternal and cord plasma and red cells. Pediatr Res 12:789-792

18. Salonen JT, Alfthan G, Pikkarainen J, Huttunen JK, Puska P 1982 Association between cardiovascular death and myocardial infarction and serum selenium in a matched pair longitudinal study. Lancet 2:175-179

19. Hafeman DG, Hoekstra WG 1977 Protection against carbon tetrachlorideinduced lipid peroxidation in the rat by dietary vitamin $\mathrm{E}$, selenium and methionine as measured by ethane evolution. J Nutr 107:656-665 